\title{
Stratification and light promote germination of ratroot (Acorus americanus (Raf.) Raf. [Acoraceae]) seeds harvested in northeastern Alberta
}

Ann Smreciu, Kimberly Gould, and Stephanie Wood

ABSTRACT

Seeds of Acorus americanus (Raf.) Raf. (Acoraceae), or ratroot as it is commonly known, were harvested from 3 locations in each of $2 \mathrm{y}$ and subjected to combinations of light and dark treatments, $30 \mathrm{~d}$ of stratification, 3 germination temperature regimes, and 4 storage durations (zero to $24 \mathrm{mo}$ ). When germinated under ambient conditions, we determined that light is required for germination and that stored seeds germinate better after stratification (moist conditions at $2-4{ }^{\circ} \mathrm{C}$ ). Observations on ideal storage time and germination temperatures, however, were inconclusive. This species is an important plant for Aboriginal peoples of northern Canada, and it is included in oil sands mining reclamation efforts.

Smreciu A, Gould K, Wood S. 2015. Stratification and light promote germination of ratroot (Acorus americanus (Raf.) Raf. [Acoraceae]) seeds harvested in northeastern Alberta. Native Plants Journal 16(1):19-22.

\section{CONVERSIONS}

$\mathrm{km} * 0.62=$ mile

$\left({ }^{\circ} \mathrm{C} \times 1.8\right)+32={ }^{\circ} \mathrm{F}$
KEY WORDS

aquatic plant, boreal forest, oil sands, Aboriginal peoples, Acoraceae

NOMENCLATURE

ITIS (2014) 
A corus americanus (Raf.) Raf. (Acoraceae), or ratroot as it is commonly known, is a species significant to Aboriginal peoples of northern Canada. Found in wetlands of the parkland and boreal regions of Alberta, this species has come to the attention of oil sands mining operators as one to include in wetland reconstruction efforts. Many studies have focused on the medicinal attributes of the closely related species, A. calamus L. (Keddy and Ellis 1985; Motley 1994; Kim and others 2009; Sigma-Aldrich 2010; Divya and others 2011), and we examined vegetative propagation (Smreciu and others 2014); however, germination of either ratroot species has not been closely examined. In an effort to provide operators with pertinent cultural information, we initiated an analysis of ratroot germination.

Although limited germination occurs without treatment, we expect that ratroot seeds would benefit from stratification (moist and cold conditions), like many other boreal wetland and upland species (Baskin and Baskin 2001), including A. calamus L. (Keddy and Ellis 1985). Other common requirements for wetland species are light and heat (Baskin and Baskin 2001). These conditions replicate the effects of a natural drawdown where retreating water exposes seed and dark soils. Because seeds are not always planted immediately, the effect of storage time was also evaluated.

\section{MATERIALS AND METHODS}

Ratroot seeds were harvested from 3 naturally occurring wetlands within $200 \mathrm{~km}$ of Fort McKay (lat $57^{\circ} 11^{\prime} 12.3^{\prime \prime} \mathrm{N}$, long $111^{\circ} 38^{\prime} 12.3^{\prime \prime} \mathrm{W}$ ) in northeastern Alberta (Figure 1). The northernmost wetland was an outlet of Kearl Lake, where plants grew in soil adjacent to a stream in which water levels fluctuate from season to season and year to year. The southernmost wet-

Figure 1. Map of Alberta showing the location of Fort McKay relative to Fort McMurray and Edmonton. Map by Jim Marin Graphics

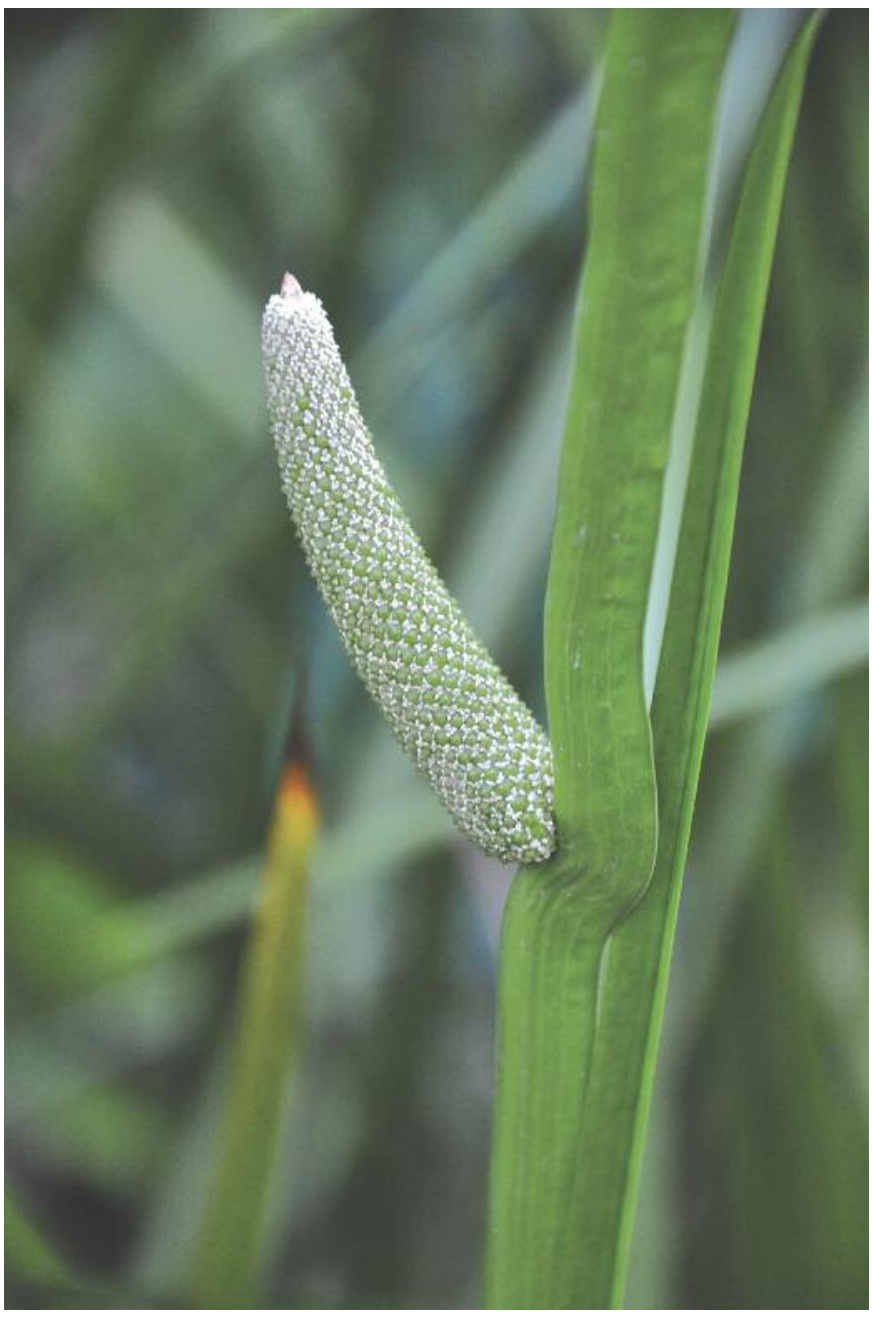

Figure 2. Immature ratroot spadix. Photo by Wild Rose Consulting Inc

land was Willow Lake, with plants growing along the shoreline. Plants were floating as part of a cattail (Typha latifolia L. [Typhaceae]) mat, connected to the shore by roots of a large willow tree. Roughly halfway between these two, Shipyard Lake lies on the Suncor mine lease. Although close to mining operations, the lake itself is relatively undisturbed as it falls in an environmental buffer maintained adjacent to the Athabasca River. Plants are found throughout the lake, floating on the surface as a constituent in cattail mats. These mats are not anchored and their configurations change frequently.

Seeds of ratroot were harvested in 2 consecutive years to incorporate variations in seed production and quality (Figure 2). Spadices were allowed to dry for a minimum of $1 \mathrm{wk}$ (up to 1 mo) before stripping seed capsules by hand. Capsules were broken up by scrubbing them on a No. 8 sieve (2.36 mm opening), catching seeds in a No. 18 sieve (1 mm opening), and finally winnowing.

Cleaned seeds were transferred to paper envelopes and stored at ambient conditions $\left(18-22{ }^{\circ} \mathrm{C}\right.$ and $30-50 \%$ relative 
humidity) for 0, 6, 12, and 24 mo. Fresh seeds and those in each storage interval were germinated in darkness (wrapped in foil) or in fluctuating light and one of 3 temperature variables $\left(5 / 15^{\circ} \mathrm{C}, 10 / 20^{\circ} \mathrm{C}\right.$, and $\left.15 / 25^{\circ} \mathrm{C}\right)$ controlled by a germination chamber with a photoperiod of $8 \mathrm{~h}$ light $/ 16 \mathrm{~h}$ dark. For each storage duration, light, and temperature treatment combination, 2 dishes of 100 seeds were placed on germination paper and moistened. Tests ran for $56 \mathrm{~d}(8 \mathrm{w})$. By the end of the second storage interval ( 1 test of fresh and 1 test of $6 \mathrm{~m}$ old seed), it was clear (germination $<5 \%$ ) that light is required for germination of ratroot seeds. In an effort to conserve seeds and costs, dark treatments were excluded from the 12 and 24 mo storage tests and the subsequent fresh and 6 mo storage tests.

All data presented are for seeds receiving a cycle of $8 \mathrm{~h}$ light and $16 \mathrm{~h}$ dark. A multivariable analysis of variance was conducted to assess the effect of site, stratification, storage time, and germination temperature at a significance level of $P<0.05$.

\section{RESULTS AND CONCLUSIONS}

Germination was observed in all treatments (except dark conditions) on all harvested seedlots (Figure 3). Storage time, stratification, and germination temperatures all significantly affected germination percentage (Table 1). No three-way interactions were significant, but the site $\mathrm{x}$ storage and stratification $\times$ storage interactions were. We detected no discernable

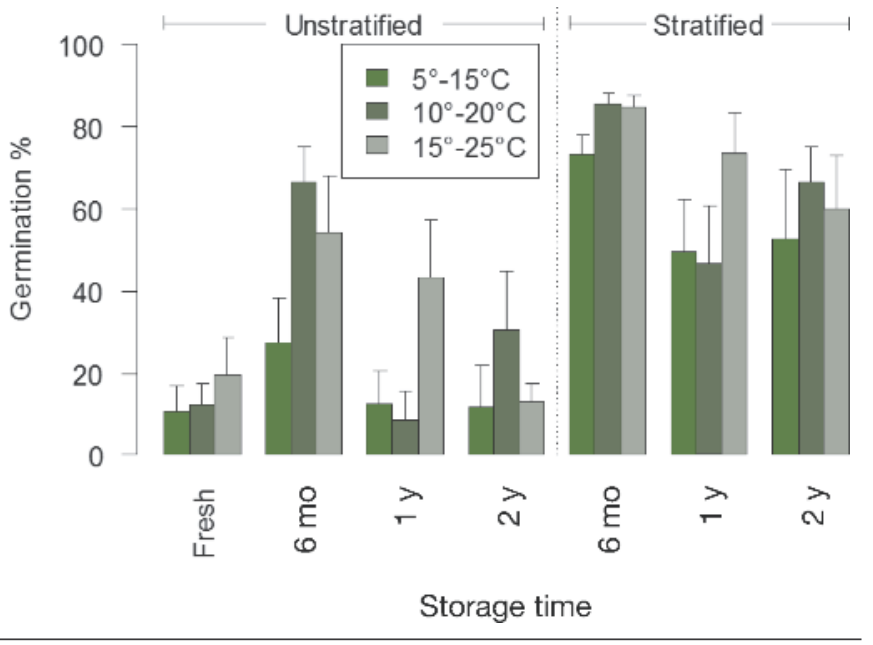

Figure 3. Ratroot germination with and without stratification across 3 temperature regimes and 4 storage durations.

pattern to the site $\mathrm{x}$ storage interaction, but non-stratified seeds show a greater decrease in germination with lengthening storage time than do seeds that are stratified. The warmest germination temperature range $\left(15 / 25^{\circ} \mathrm{C}\right)$ resulted in significantly greater germination percentages than the lowest range $\left(5 / 15^{\circ} \mathrm{C}\right)(P=0.0346)$; neither was significantly different from the middle range of $10 / 20^{\circ} \mathrm{C}$. Seeds stored for 6 mo germinated more than seeds stored for any other tested period $(P<0.05)$.

TABLE 1

Analysis of variance table for germination data.

\begin{tabular}{|c|c|c|c|c|c|}
\hline Variable & Df & Sum sq & Mean sq & $F$ value & $P$ value \\
\hline Site & 2 & 3383 & 1691 & 2.1745 & 2.1745 \\
\hline Stratification (Strat) & 1 & 49109 & 49109 & 63.883 & $<0.0001$ \\
\hline Storage & 3 & 19659 & 6553 & 9.6125 & $<0.0001$ \\
\hline Temperature (Temp) & 2 & 5605 & 2803 & 4.1110 & 0.0210 \\
\hline Site $\times$ Strat & 2 & 399 & 199 & 0.2926 & 0.7473 \\
\hline Site $\times$ Storage & 6 & 10807 & 1801 & 2.642 & 0.0238 \\
\hline Site $\times$ Temp & 4 & 1494 & 374 & 0.5480 & 0.7012 \\
\hline Strat $\times$ Storage & 2 & 402 & 201 & 0.2947 & 0.0238 \\
\hline Strat $\times$ Temp & 2 & 188 & 94 & 0.1377 & 0.8717 \\
\hline Storage $\times$ Temp & 6 & 7818 & 1303 & 1.9113 & 0.0927 \\
\hline Site $\times$ Strat $\times$ Storage & 4 & 1160 & 290 & 0.4253 & 0.7898 \\
\hline Site $\times$ Strat $\times$ Temp & 4 & 1139 & 285 & 0.4175 & 0.7954 \\
\hline Site $\times$ Storage $\times$ Temp & 12 & 3093 & 258 & 0.3781 & 0.9667 \\
\hline Strat $\times$ Storage $\times$ Temp & 4 & 935 & 234 & 0.3430 & 0.8479 \\
\hline Site $\times$ Strat $\times$ Storage $\times$ Temp & 8 & 714 & 89 & 0.1309 & 0.9976 \\
\hline Residuals & 63 & 42948 & 682 & - & - \\
\hline
\end{tabular}


Overall, fresh seeds germinated less than any other tested period $(P<0.05)$. In general, 6 mo of storage and warmer temperatures benefit germination. Stratification improves germination percentages over the range of germination temperatures and storage times. Seed storage conditions were not tested in this study but it would be worth examining seeds stored at low temperatures under low relative humidity to determine if germination of older seeds can be improved compared with that observed in this study. This approach would inform whether the seed storage behavior is orthodox.

\section{ACKNOWLEDGMENTS}

We thank our funders, operators in the Athabasca Oil Sands and members of the Canadian Oil Sands Network for Research and Development Environmental and Reclamation Research Group (CONRAD ERRG): Canadian Natural Resources Limited, Imperial Oil Limited, Shell Canada Limited, Suncor Energy Incorporated, Syncrude Canada Limited, and Total E\&P Canada Limited. We also thank 20/20 Seed Labs Incorporated for their facilities and expertise.

\section{REFERENCES}

Baskin CC, Baskin JM. 2001. Seeds: ecology, biogeography and evolution of dormancy and germination. San Diego (CA): Academic Press. 666 p.

Divya G, Gajalakshmi S, Mythili S, Sathiavelu A. 2011. Pharmacological activities of Acorus calamus: a review. Asian Journal of Biochemical and Pharmaceutical Research 1(4):57-64.

[ITIS] Integrated Taxonomic Information System. 2014. Acorus americanus. URL: http://itis.gov (accessed 15 Jul 2014). Washington (DC): National Museum of Natural History.

Keddy PA, Ellis TH. 1985. Seedling recruitment of 11 wetland plant species along a water level gradient: shared or distinct responses? Canadian Journal of Botany 63:1876-1879.

Kim H, Han T, Lee S. 2009. Anti-inflammatory activity of a water extract of Acorus calamus L. leaves on keratinocyte $\mathrm{HaCaT}$ cells. Journal of Ethnopharmacology 122(1):149-156.

Motley TJ. 1994. The ethnobotany of sweet flag, Acorus calamus (Araceae). Economic Botany 48(4):397-412.

Sigma-Aldrich. 2010. Calamus (Acorus calamus). URL: http://www .sigmaaldrich.com/life-science/nutrition-research/learningcenter/plant-profiler/acorus-calamus.html (accessed 16 Jan 2014). Somerville (MA): Natural Standard Corporation.

Smreciu A, Wood S, Gould K, Wood B. 2014. Propagation protocol for ratroot (Acorus americanus). Native Plants Journal 15(3):219-221.

\section{AUTHOR INFORMATION}

\section{Ann Smreciu}

Wildrose.consulting@shaw.ca

Kimberly Gould

Kim.wildrose@shaw.ca

Stephanie Wood

Steph.wood@live.com

Wild Rose Consulting Inc

15109-77th Avenue

Edmonton, Alberta T5R 1L4

\section{The Largest Wholesale Aquatic} Nursery in the Midwest

Illinois $\cdot$ Indiana $\cdot$ lowa $\cdot$ Michigan $\cdot$ Minnesota $\cdot$ Ohio $\cdot$ Wisconsin

\section{Producers of Plant Materials for Large Scale Wetland Mitigation and Native Restoration Quality Native Plants}

Specialty Services Including: - Licensed Herbiciding - Site Consultation -Mowing/Maintenance -Prescribed Buming - No Till Drilling -Straw Blowing/Crimping
- Delineation, Mitigation, \& Monitoring - Contract Growing Available -Planting Installation - Largest Selection -Best Quality -Wholesale Prices

-Potted and Bare-Root Material
Installation Services for: - Habitat Restoration -Waste Water Treatment - Erosion Control - Bioengineering - Mine Reclamation

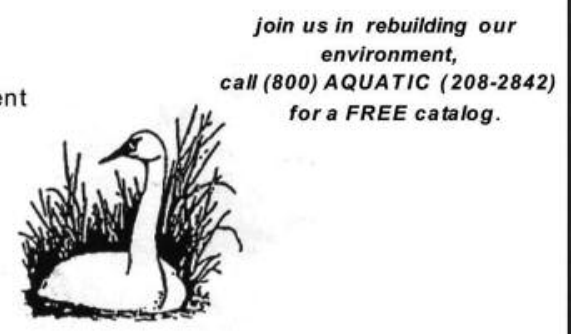

MARSHLAND TRANSPLANT AQUATIC NURSERY P.O. Box 1 Berlin, WI 54923

(920)361-4200 Fax (24 hours): (920)361-4200 e-mail marshland@centurytel.net 